\title{
6. A 2020-as Covid-veszélyhelyzet alkotmányjogi szemmel ${ }^{1}$
}

\section{HORVÁTH ATTILA}

\section{A Covid-19 elötti veszélyhelyzetek}

Bár az Alaptörvény jelenleg hat különböző különleges jogrendi tényállást ismer, ezek közül - hozzátehetjük: szerencsére - egyedül a veszélyhelyzet hatályosult. ${ }^{2}$ A 2020. március 11-én kihirdetett veszélyhelyzet nem az első volt Magyarországon - annyira nem, hogy a Kormány a rendszerváltás óta nem kevesebb mint 16 alkalommal hozott már ilyen döntést. Amint a 3. táblázatból kitúnik, a veszélyhelyzetre okot adó körülmény 15 alkalommal az árvíz és a belvíz volt, ${ }^{3}$ egyszer pedig - a 2010-es kolontári iszapkatasztrófa nyomán - ipari baleset miatt kellett veszélyhelyzetet hirdetni.

1 Jelen fejezet a szerző A veszélyhelyzet közjogi és jogalkotási dilemmái-mérlegen az Alaptörvény 53. cikke címû, a Közjogi Szemle 2020/4. számában megjelent tanulmányának bővített és aktualizált változata.

2 Till, 2019, [14].

3 A 15 ár-/belvizes veszélyhelyzet valójában kevesebb, hét időszakra vonatkozik, azonban a Kormány egyes esetekben - akár néhány nap különbséggel - több veszélyhelyzetet kihirdető rendeletet is kiadott, többnyire eltérő területi hatállyal.

Dr. Horváth Attila, PhD

attila.horvath@mfi.gov.hu

vezető kutató (Mádl Ferenc Összehasonlító Jogi Intézet)

adjunktus (Nemzeti Közszolgálati Egyetem Államtudományi és Nemzetközi Tanulmányok Kar, Alkotmányjogi és Összehasonlító Közjogi Tanszék)

Horváth, A. (2021) 'A 2020-as Covid-veszélyhelyzet alkotmányjogi szemmel' in Nagy, Z., Horváth, A. (szerk.) A különleges jogrend és nemzeti szabályozási modelljei, 149-173. o. Budapest: Mádl Ferenc Összehasonlító Jogi Intézet.

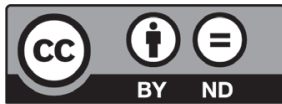




\begin{tabular}{|c|c|c|c|c|}
\hline & $\begin{array}{l}\text { Veszélyhelyzetet kihirdető } \\
\text { kormányrendelet }\end{array}$ & $\begin{array}{l}\text { Veszélyhely- } \\
\text { zetre okot adó } \\
\text { körülmény }\end{array}$ & Területi hatály ${ }^{4}$ & $\begin{array}{c}\text { Hatály } \\
\text { időtartama }\end{array}$ \\
\hline 1. & 47/2000. (IV. 10.) Korm. rendelet & árvíz & 9 megye & 32 nap \\
\hline 2. & 40/2001. (III. 6.) Korm. rendelet & árvíz & 1 megye & n. a. ${ }^{5}$ \\
\hline 3. & 176/2002. (VIII. 15.) Korm. rendelet & árvíz & 3 megye és a föváros & 6 nap $^{6}$ \\
\hline 4. & 76/2006. (IV. 3.) Korm. rendelet & árvíz & Duna és Ipoly egyes szakaszai & $7 \mathrm{nap}^{7}$ \\
\hline 5. & 87/2006. (IV. 14.) Korm. rendelet & árvíz & Tisza egyes szakaszai & 11 nap \\
\hline 6. & 101/2006. (IV. 25.) Korm. rendelet & árvíz & Tisza egyes szakaszai & 14 nap \\
\hline 7. & 183/2010. (V. 17.) Korm. rendelet & árvíz & 1 megye & 8 nap \\
\hline 8. & 186/2010. (VI. 2.) Korm. rendelet & árvíz és belvíz & 1 megye & 15 nap \\
\hline 9. & 187/2010. (VI. 2.) Korm. rendelet & árvíz & 1 megye & 7 nap \\
\hline 10. & 188/2010. (VI. 3.) Korm. rendelet & árvíz és belvíz & 2 megye & 14 nap \\
\hline 11. & 189/2010. (VI. 4.) Korm. rendelet & árvíz és belvíz & 8 megye & 13 nap \\
\hline 12. & 245/2010. (X. 6.) Korm. rendelet & ipari baleset & 3 megye & 267 nap \\
\hline 13. & 1/2011. (I. 12.) Korm. rendelet & árvíz & I megye & 43 nap \\
\hline 14. & 15/2011. (II. 24.) Korm. rendelet & árvíz & 1 megye & n. a. ${ }^{8}$ \\
\hline 15. & 177/2013. (VI. 4.) Korm. rendelet & árvíz & 3 megye és a fôváros & 46 nap \\
\hline 16. & 191/2013. (VI. 10.) Korm. rendelet ${ }^{9}$ & árvíz & 5 megye & 40 nap \\
\hline
\end{tabular}

3. táblázat

A 2020 elött kihirdetett veszélyhelyzetek jellemzöi

Forrás: a szerző saját összeállítása

4 A területi hatály csak hozzávetőlegesen, egyszerűsítve került feltüntetve a táblázatban (a járási szintủ megjelölést mellőztük).

5 A 40/2001. (III. 6.) Korm. rendeletet formálisan csak 2004. május 1-jével - egy átfogó deregulációs jogszabály [105/2004. (IV. 27.) Korm. rendelet] keretében - helyezték hatályon kívül, de a veszélyhelyzet értelemszerủen nem állt fenn több mint három éven át. (A jogalkotó tehát egyszerúen csak „megfeledkezett” a veszélyhelyzetet kihirdető kormányrendelet hatályon kívül helyezéséről.)

6 A veszélyhelyzetet a 179/2002. (VIII. 21.) Korm. rendelet ugyan 2002. augusztus 21-i hatállyal feloldotta, azonban a veszélyhelyzetet kihirdető kormányrendeletet csak az előbbi lábjegyzetben említett deregulációs kormányrendelet helyezte hatályon kívül.

7 A veszélyhelyzetet a 85/2006. (IV. 10.) Korm. rendelet ugyan 2006. április 10-i hatállyal feloldotta, azonban a veszélyhelyzetet kihirdető kormányrendeletet csak a 118/2008. (V. 8.) Korm. rendelet helyezte hatályon kívül.

8 A 15/2011. (II. 24.) Korm. rendeletet formálisan csak 2014. szeptember 5-ével - egy átfogó deregulációs jogszabály [222/2014. (IX. 4.) Korm. rendelet] keretében - helyezték hatályon kívül, de a veszélyhelyzet természetesen ezúttal sem állt fenn három és fél éven át.

9 A kormányrendelet formailag egy módosító jogszabály volt, azonban egyúttal veszélyhelyzetet is hirdetett. 
Annak, hogy a médiában - és esetenként a szakirodalomban is ${ }^{10}$ - találkozhattunk olyan állításokkal, hogy ez volt az első kihirdetett veszélyhelyzet - vagy általában különleges jogrend -, valószínűleg az lehet az oka, hogy a Covid-19 miatti veszélyhelyzet a jelentőségét, a következményeit és nem utolsósorban az általa kiváltott közjogi-politikai vitákat tekintve eddig egyedülálló fejleménynek bizonyult hazánkban, és természetesen gyökeresen különbözik a korábbiaktól.

Egyrészt a 2020 előtti veszélyhelyzetek területi hatálya minden esetben egy-egy körülhatárolt földrajzi egységre (többnyire egy vagy több megyére vagy járásra) terjedt ki, azonban a Covid-19 miatti veszélyhelyzet országos hatállyal került kihirdetésre, azaz egyfajta „általános veszélyhelyzet ${ }^{{ }^{11}}$ volt. Másrészt a korábbi veszélyhelyzetek - a kolontári iszapkatasztrófa kivételével - jóval rövidebb idôtartamra korlátozódtak, míg a járvány miatti veszélyhelyzet 99 napig tartott. A harmadik - és a legfontosabb - különbség a veszélyhelyzettel járó intézkedésekhez kötődik. A korábbi kihirdető rendeletek által bevezetett rendkívüli intézkedések értelemszerúen az árvíz-/belvízveszéllyel szembeni védekezéshez - mint egy lokális problémához - kapcsolódó rendelkezések voltak (így például a közlekedés korlátozása, kitelepítés, közterületi rendezvény vagy nyilvános gyưlés megtiltása, szabad mozgás korlátozása), amelyek ugyan mutatnak részbeni átfedést a 2020-as rendkívüli intézkedésekkel, azonban a lakosságnak egy viszonylag szúk körét érintették. A vírus miatti veszélyhelyzet viszont az állampolgárok széles körének mindennapjait, az állam és a gazdaság múködését alapvetően befolyásoló, hosszú távú hatásokkal járó időszaknak bizonyult - és bizonyul napjainkban is.

A veszélyhelyzet és annak életünk szinte minden szegmensére kiható következményei természetesen rövidesen tudományos vizsgálatok tárgyává is váltak. A veszélyhelyzet értelemszerúen ezer szállal kötődik a joghoz, így a jogtudomány múvelői is látványosan növekvő érdeklődést tanúsítanak a korábban talán némileg elhanyagolt témakör iránt. ${ }^{12}$ Ebben a fejezetben a 2020. márciustól decemberig tartó időszak közjogi és jogalkotási dilemmáira fókuszálunk, különös tekintettel az Alaptörvény veszélyhelyzetet szabályozó 53. cikkére. (A veszélyhelyzet bevezetésének és a veszélyhelyzeti jogalkotásnak jóval több alkotmányjogi problémája van, mint amennyire ki fogunk térni, így a fejezet természetesen nem minősül teljes körü áttekintésnek.)

A következőkben elsőként azt a kérdést járjuk körül, hogy egyáltalán szükség volt-e veszélyhelyzet kihirdetésére. Ezt követôen az Alaptörvény, valamint a katasztrófavédelemról és a hozzá kapcsolódó egyes törvények módosításáról szóló 2011. évi CXXVIII. törvény (Kat.) kapcsolatát és valószínűsíthetô ütközését tárgyaljuk; majd a veszélyhelyzeteket kihirdető rendeleteket vizsgáljuk. A fejezet 5. pontja az Alaptörvény veszélyhelyzetet szabályozó 53. cikkének belső koherenciáját elemzi, majd a veszélyhelyzet(i kormányrendeletek) meghoszszabbításával kapcsolatban felmerülő értelmezési problémákat vázoljuk fel. Az összegzést

10 Így például Mészáros „a rendszerváltás utáni Magyarországon először bevezetett különleges jogrend”-ről ír (Mészáros, 2019, 69. o.).

11 Balázs-Hoffman, 2020, 1. o.

12 Lásd például a Glossa Iuridica folyóirat Jog és erkölcs címü különszámát vagy a Társadalomtudományi Kutatóközpont Jogtudományi Intézet Epidemiológia és jogtudomány című kutatási projektjét. 
követően röviden kitérünk az Alaptörvény kilencedik módosítására is, amelyet a jelen kötet kéziratának lezárásakor fogadott el az Országgyưlés, és amely gyökeresen átalakítja a különleges jogrendre vonatkozó szabályozást, és egyben - amint látni fogjuk - a tanulmány által felvetett problémák egy részére is megoldást kínál.

\section{Szükség volt-e veszélyhelyzet kihirdetésére?}

A veszélyhelyzet 2020. március 11-i bevezetését követően rövidesen megjelentek azok a szakmai álláspontok, amelyek szerint a járványra hivatkozva egyrészt szükségtelen és indokolatlan a különleges jogrend kihirdetéséhez folyamodni, másrészt pedig a Kormánynak eleve nem is lett volna jogi lehetősége a különleges jogrend kihirdetésére, ugyanis a járvány nem alapozhatja meg a veszélyhelyzet bevezetését. A következőkben az előbbi ellenérvet vizsgáljuk meg, majd a 3. pontban az utóbbi álláspontot tárgyaljuk.

A veszélyhelyzet bevezetését szükségtelennek és indokolatlannak tartó álláspontok ${ }^{13}$ arra hivatkoztak, hogy a járvány normál jogrendi körülmények között is kezelhetô lett volna, ugyanis ehhez az egészségügyi törvényben ${ }^{14}$ megtalálhatók a megfelelố rendelkezések. Az Eütv. a népegészségügyi fejezetben egyrészt külön alcím alatt foglalkozik a járványüggyel, ${ }_{15}^{15}$ másrészt pedig a törvény 2012. január 1-je óta szabályozza az úgynevezett egészségügyi válsághelyzetet és az egészségügyi veszélyhelyzeti ellátást. ${ }^{16} \mathrm{Ami}$ az Eütv. járványügyi rendelkezéseit illeti, kétségtelen, hogy a jogszabály számos korlátozásra ad lehetőséget, ráadásul - mutat rá a kommentár - „[a] hatályos magyar közrendi jellegú járványügyi szabályozás hagyományosan és európai összehasonlításban is meglehetősen szigorú. A szabályozás imperativitását tekintve nemcsak a már kialakult járványügyi veszélyhelyzet esetében, hanem a preventív ellátások igénybevételére kötelezés területén is kifejezetten »aktivista «. ${ }^{{ }_{17} 7} \mathrm{Az}$ Eütv. értelmében a járványügyi tevékenység célja - többek között a fertőző megbetegedések, a járványok megelőzése és leküzdése, ${ }^{18}$ és ennek érdekében a következő jogosítványok állnak a hatóságok rendelkezésére (a felsorolás nem teljes körü)::19

— az egyén személyes szabadsághoz való jogának korlátozása; ${ }^{20}$

- betegjogok korlátozása; ${ }^{21}$

13 Lásd például: Mészáros, 2019; Lattmann, 2020.

$14 \mathrm{Az}$ egészségügyről szóló 1997. évi CLIV. törvény (Eütv.).

15 Eütv. III. fejezet 6. cím.

16 Eütv. XIV. fejezet. 2012 előtt „katasztrófa-egészségügyi ellátás” elnevezéssel tartalmazott hasonló rendelkezéseket.

17 Dósa-Hanti-Kovácsy, 2016, 154. 0.

18 Eütv. 56. \$(1) bekezdés.

19 A következőkben az Eütv.-nek a veszélyhelyzet kihirdetésekor hatályos szövegváltozatát vesszük alapul, hiszen a 2020. márciusi jogi szabályozást vizsgáljuk. Az Eütv. 2020. júniusi módosítása a járványügyi rendelkezéseket is kiegészítette, bevezetve például a hatósági házi karantén intézményét (a veszélyhelyzet megszúnésével összefüggő átmeneti szabályokról és a járványügyi készültségről szóló 2020. évi LVIII. törvény 309. \$).

20 Eütv. 56. $\$(2)$ bekezdés $a$ ) pont $a a$ ) alpont.

21 Eütv. 56. $\$(2)$ bekezdés $a$ ) pont $a b$ ) alpont és $b$ ) pont. 
- a törvényben meghatározott intézkedések tűrésére, illetve megtételére kötelezés;22

- járványügyi elkülönítés; ${ }^{23}$

— járványügyi megfigyelés; ${ }^{24}$

- járványügyi zárlat; ${ }^{25}$

— járványügyi ellenőrzés; ${ }^{26}$

— személy felkutatása járványügyi intézkedés végrehajtása érdekében. ${ }^{27}$

Az Eütv. az Egyéb járványügyi intézkedések alcím alatt járvány esetén - többek között a következők korlátozását vagy megtiltását teszi lehetővé: ${ }^{28}$

- minden olyan intézmény múködése, illetve rendezvény és tevékenység, amely a járvány terjedését elősegítheti;

— az egyes területek közötti személyforgalom, élőállat- vagy áruszállítás;

- az egyes területek lakosainak más területek lakosaival való érintkezése;

- a fekvőbeteg-gyógyintézet látogatása;

— az egyes területek elhagyása.

A járványügyi rendelkezések mellett az Eütv.-ből az egészségügyi válsághelyzet érdemel alaposabb figyelmet. ${ }^{29}$ Hangsúlyozandó, hogy ez nem minősül különleges jogrendnek, hanem csupán egy speciális ellátási formának, ${ }^{30}$ amelynek a bevezetése akkor indokolt, „amikor valamilyen rendkívüli helyzetben az ellátási igények és lehetőségek diszkrepanciája miatt szükségképpen szúkebbek az ellátási opciók, nem teljesen érvényesülhetnek az ellátói és betegjogok, valamint kötelezettségek". ${ }^{31}$ A törvény értelmében egészségügyi válsághelyzetnek - többek között - a következő események minősültek:32

- minden - rendszerint váratlanul bekövetkező - esemény, amely a polgárok életét, testi épségét, egészségét vagy az egészségügyi szolgáltatók múködését veszélyezteti

22 Eütv. 56. $\$(2)$ bekezdés $a$ ) pont $a c$ ) alpont.

23 Eütv. 63-64. $\$$.

24 Eütv. 65-67. \$.

25 Eütv. 65-67. \$.

26 Eütv. 68-70. $\$$.

27 Eütv. 70/A. \$.

28 Eütv. 74. $\$(2)$ bekezdés $a)-e$ ) pont.

29 Itt ismét felhívjuk a figyelmet, hogy az Eütv. 2020. márciusi szövegváltozatát vizsgáljuk.

30 A különleges jogrend és az egészségügyi válsághelyzet viszonyát tisztázza az a rendelkezés, amely szerint különleges jogrend bevezetésekor az egészségügyi válsághelyzeti ellátásra vonatkozó rendelkezéseket kell alkalmazni az egész országra kiterjedően, azonban ez esetben nem szükséges az egészségügyi válsághelyzet kihirdetése [Eütv. 228. \$ (3) bekezdés]. Itt kell megjegyezni, hogy az Eütv. kapcsolódó (XIV.) fejezete az Egészségügyi válsághelyzeti és egészségügyi veszélyhelyzeti ellátás címet viseli, azonban a törvényben később nem fordul elő az egészségügyi veszélyhelyzeti ellátás kifejezés; helyette az egészségügyi válsághelyzeti ellátás kifejezést használja.

31 Dósa-Hanti-Kovácsy, 2016, 473-474. o.

32 Eütv. 228. $\$(2)$ bekezdés. 
vagy károsítja olyan mértékben, hogy az az egészségügyi ellátási szükségletek és a helyben rendelkezésre álló kapacitás közötti aránytalanság kialakulásához vezet;

— nemzetközi horderejû́ közegészségügyi-járványügyi szükséghelyzet (függetlenül attól, hogy erre különleges jogrend idején vagy azon kívül kerül sor).

Egészségügyi válsághelyzet esetén az általános szabályoktól több szempontból is el lehet térni33 - így például a betegjogok csak akkor és kizárólag olyan mértékben gyakorolhatók, amikor és amennyiben nem veszélyeztetik az egészségügyi válsághelyzet felszámolásának eredményességét; ${ }^{34}$ az egészségügyi ellátórendszerre, az egészségügyi szolgáltatás szakmai követelményeire, valamint az egészségügyi dolgozók jogaira és kötelezettségeire elő́rt rendelkezéseket pedig bizonyos eltérésekkel kell alkalmazni. ${ }^{35}$

Miután röviden felvázoltuk az Eütv. releváns rendelkezéseit, adott a kérdés: a fenti szabályozási keretek között valóban meg lehetett-e volna oldani a Covid-19 kezelését? Mészáros Gábor a 2020. március végén (tehát még a járványhelyzet igazi eszkalálódása elôtt) írt elemzésében - miután összefoglalta az Eütv. kapcsolódó szabályozását - erre összességében igenlő választ adott: „A fentiek alapján is látható, hogy az Eütv. megalkotásakor a jogalkotó készült a koronavírus okozta járványhoz hasonló helyzetekre; ez a jogszabály biztosítja a rendes jogi múködés keretében a helyzet kezelésének lehetőségét. A körülmények tehát nem feltétlenül teszik szükségessé különleges jogrend alkalmazását [...].”36 Amint az Igazságügyi Minisztérium jogszabály-előkészítés összehangolásáért és a közjogi jogalkotásért felelős helyettes államtitkárának tanulmányából kiderül, eleinte (2020. március elején) még valóban az egészségügyi válsághelyzet kihirdetése tûnt kézenfekvő megoldásnak, azonban március 9-én már egyértelmúvé vált, hogy ez „legfeljebb ideiglenesen tudna eszköztárat biztosítani a járvány hatásainak kezelésére, hosszabb távon a különleges jogrend intézményéhez, a veszélyhelyzethez kell nyúlni”. ${ }^{37}$

A fenti vitát utólagosan, mintegy 9 hónap távlatából nem lenne méltányos „eldönteni”, ráadásul jóval alaposabb elemzésre lenne szükség annak megítéléséhez, hogy a veszélyhelyzet alatt a Kormány által meghozott több száz intézkedés mindegyike „belefért” volna-e a normál jogrendi múködésbe. Az viszont egyértelmủen kijelenthető - és ez már 2020 . március végén látható volt -, hogy a Covid-19-járványra nem lehet(ett) kizárólag egészségügyi problémaként tekinteni, hiszen a pandémiás helyzetnek szinte felmérhetetlenül jelentősek a gazdasági, munkaerőpiaci, szociális stb. hatásai is. Másrészt az is kérdéses, hogy az Eütv. egyes - fentebb hivatkozott - rendelkezései vajon valóban jogalapot szolgáltathattak volna-e a Kormány által meghozott olyan intéz-

33 Megjegyzendő, hogy az ellátói válsághelyzet [Eütv. 228. \$ (2) bekezdés b) pont] az egyébként a válsághelyzeti ellátásra előírt rendkívüli szabályok közül számos nem alkalmazható (Eütv. 232/A. \$). Az egészségügyi válsághelyzeti ellátás részletes szabályait az egészségügyi válsághelyzeti ellátásról szóló 521/2013. (XII. 30.) Korm. rendelet tartalmazza.

34 Eütv. 229. \$ (1) bekezdés.

35 Eütv. 229. \$(2) bekezdés.

36 Mészáros, 2019, 67. o.

37 Salgó, 2020, 12-13. o. 
kedésekhez, mint például a látogatási tilalom elrendelése a felsőoktatási intézményekben vagy a kijárási korlátozás? Itt ismét fel kell idézni az Eütv.-nek azt a rendelkezését, amely első olvasatra rendkívül széles jogköröket biztosít az egészségügyi államigazgatási szerv (azaz ebben az esetben a járási hivatal) részére: „Járvány esetén korlátozható vagy megtiltható minden olyan intézmény múkködése, illetve rendezvény és tevékenység, amely a járvány terjedését elősegítheti. ${ }^{{ }^{38}}$ Mészáros ezen rendelkezésre hivatkozva úgy érvelt, hogy az Eütv. is lehetôvé tette volna az oktatási intézmények bezárását, a tömegrendezvények megtiltását, az ország területének elhagyását, valamint a személyforgalom korlátozását. ${ }^{39} \mathrm{~A}$ rendelkezés megfogalmazásából valóban az következik, hogy lényegében „minden” korlátozható vagy megtiltható, hiszen az intézmény-rendezvény-tevékenység hármas értelmezése tetszőlegesen széles lehet, ugyanis aligha van az életnek olyan szegmense, ami ne lenne besorolható a három fogalom valamelyikébe. (Az Eütv. hasonlóan tág jogköröket biztosít a személyforgalom, valamint egyes területek elhagyásának korlátozásával/megtiltásával

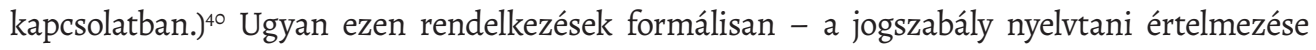
alapján - valóban lehetőséget adtak volna a különböző bezárásokra és a kijárási korlátozásokra is (hiszen például az egyetem is tekinthető intézménynek, márpedig akkor be is zárható), azonban két ellenvetés is tehetô. Egyrészt úgy véljük, hogy az Eütv. hivatkozott rendelkezéseinek kodifikálásakor aligha egy globális, így az egész országot hónapokra-évekre megbénító járvány lebegett a jogalkotó szeme előtt. Életszerütlennek és a törvény szellemiségével ellentétesnek tartanánk, ha az összes oktatási intézményre kiterjedő, hónapokon át tartó, a társadalom jelentős részét érintő bezárásáról egy Kormány alatti szakigazgatási hatóság döntene. (Nem igényel különösebb magyarázatot, hogy ez utóbbi más kategória, mint például egy általános iskola bezáratása egy hétre.) Másrészt arra is rá kell mutatni, hogy az országos tisztifőorvos - nem lévén jogalkotó - jogszabályban értelemszerúen nem rendelhette volna el ezeket a tiltásokat és korlátozásokat. Jogszabály híján marad az egyedi határozat, valamint a normatív utasítás, azonban egyik sem minősülhetett volna jogszerú megoldásnak. Az egyedi határozatnak nem lehet célja a jogalanyok magatartásának általános jelleggel való szabályozása, a normatív utasításban pedig csak a vezetése, az irányítása vagy a felügyelete alá tartozó szervek szervezetét és múködését, valamint tevékenységét szabályozhatja az országos tiszti fóorvos (mint a központi hivatal vezetője). ${ }^{41}$

A fentiek alapján összességében azon az állásponton vagyunk, hogy a veszélyhelyzet kihirdetése nélkül aligha lett volna kezelhető a Covid-19-járványhelyzet. (Mindez azonban távolról sem jelenti azt, hogy ne merültek volna fel jogi aggályok a különleges jogrend során, mint ahogy azt sem, hogy a hazai jogrendszer teljes egészében alkalmas lett volna a helyzet kezelésére.)

38 Eütv. 74. $\$(2)$ bekezdés $a)$ pont.

39 Mészáros, 2019, 68. o.

40 Eütv. 74. $\$(2)$ bekezdés b) és $d$ ) pont.

41 Vö.: a jogalkotásról szóló 2010. évi CXXX. törvény 23. \$ (4) bekezdés c) pont. 2020. március végén - a veszélyhelyzet kihirdetését követóen megalkotott kormányrendeletek hatályvesztése miatt - az országos tiszti fóorvos mégis rákényszerült, hogy határozatban „hosszabbítsa meg” egyes kormányrendeletek hatályát. Balázs és Hoffman meggyőzően bizonyítja, hogy ez a határozat - egyfajta „pszeudonorma” - semmilyen értelmezés alapján nem volt jogszerünek minősíthető. (Balázs-Hoffman, 2020, 3. o.). 


\section{Veszélyhelyzet vs. járvány: az Alaptörvény és a katasztrófavédelmi törvény kapcsolata}

A veszélyhelyzet kihirdetését követően megfogalmazódott kritikák azt is szóvá tették, hogy a Kormánynak a járványra hivatkozva nem lett volna lehetősége a különleges jogrend bevezetésére, ${ }^{42}$ ugyanis az Alaptörvény 53 . cikk (1) bekezdése csak két esetben teszi lehetôvvé a veszélyhelyzet kihirdetését: az egyik az élet- és vagyonbiztonságot veszélyeztető elemi csapás, a másik pedig - értelemszerúen az élet- és vagyonbiztonságot szintén veszélyeztető - ipari szerencsétlenség.

Az Alaptörvény és a Kat. kapcsolatát illusztrálja a következő ábra, amely mintegy összekapcsolja az alaptörvényi és a törvényi rendelkezéseket:

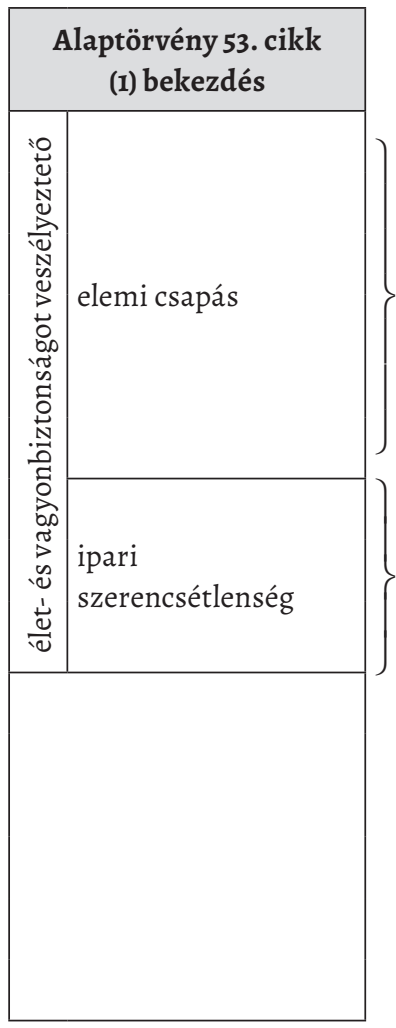

\begin{tabular}{|l|}
\hline \multicolumn{1}{|c|}{ Kat. 44. § } \\
\hline a) elemi csapások, természeti eredetû́ veszélyek, különösen \\
\hline aa) árvíz* \\
\hline ab) belvíz* \\
\hline ac) hóesés* \\
\hline ad) más szélsőséges idójárás* \\
\hline ae) földtani veszélyforrások \\
\hline b) ipari szerencsétlenség, civilizációs eredetú veszélyek, különösen \\
\hline ba) a veszélyes anyagok és hulladékok szabadba kerülése* \\
\hline bb) nem tervezett radioaktív kiszóródás és egyéb sugárterhelés* \\
\hline c) egyéb eredetú veszélyek, különösen \\
\hline $\begin{array}{l}\text { ca) tömeges megbetegedést okozó humánjárvány vagy járvány- } \\
\text { veszély, valamint állatjárvány }\end{array}$ \\
\hline cb) ivóvíz szennyeződése* \\
\hline cc) légszennyezettség* \\
\hline cd) kritikus infrastruktúrák múködési zavara* \\
\hline
\end{tabular}

$$
\text { 5. ábra }
$$

Az Alaptörvény és a Kat. kapcsolata

Forrás: a szerző saját összeállítása

(Megjegyzés: a csillaggal jelölt tényállások egyszerüsittett/röviditett formában kerültek feltüntetésre)

42 A publicisztikák közül lásd például: Lattmann, 2020; Schiffer, 2020; Tordai, 2020. A tudományos közlemények közül lásd például: Mészáros, 2019; Szente, 2020. 
A Kat. 44. \$-át alaposabban megvizsgálva két - egymással szorosan összefüggő aggály merülhet fel. Egyrészt a szakasz felvezető szövege a következő: „A veszélyhelyzet az Alaptörvény 53. cikkében meghatározott olyan helyzet, amelyet különösen a következő események válthatnak ki: [...]." A különösen kifejezés használata egyértelmúsíti, hogy a jogalkotó a 44. \$ három fố elemből [a)-c) pontok] álló felsorolását nem tekinti taxatívnak, noha az Alaptörvény 53. cikk (1) bekezdése kizárólag az elemi csapás és az ipari szerencsétlenség esetén teszi lehetővé a veszélyhelyzet kihirdetését. A különösen kitétel visszaköszön az a)-c) pontok mindegyikében, vagyis ezek a felsorolások sem taxatívak, hanem pusztán példálózó jellegúek. Ezen utóbbi megoldás azonban álláspontunk szerint nem kifogásolható, ugyanis célszerûtlen lenne elvárni a jogalkotótól, hogy például az elemi csapások összes lehetséges megnyilvánulási formáját számba vegye. [Egy hipotetikus - Magyarországon persze meglehetősen valószínútlen - példával megvilágítva: egy több megyére kiterjedô túzvész esetén az a) pont annak ellenére is alkalmazható lenne, hogy az alpontokban nincs megemlítve a tûzvész.]

A másik probléma a Kat. 44. \$c) pontja, amely az egyéb eredetú veszélyek kategóriáját megalkotva mintegy kiegészíti az Alaptörvény kapcsolódó rendelkezését. Ebben a pontban kapott helyet a veszélyhelyzet kihirdetését megalapozó ca) alpont is (tömeges megbetegedést okozó humánjárvány vagy járványveszély). Szente Zoltán szerint a c) pont „az Alaptörvény által a veszélyhelyzetre vonatkozó tényállások önkényes kiterjesztése, amelyre az Országgyúlésnek nem volt felhatalmazása”, és így „az alaptörvény-ellenes módon terjeszkedik túl az Alaptörvény szövegén". ${ }^{43}$ Hasonlóan érvel Mészáros, rámutatva egyúttal arra is, hogy a Kat.-nak eleve nem lenne feladata a veszélyhelyzetet előidéző körülmények pontos meghatározása, ugyanis az Alaptörvény 53. cikk (1) bekezdése értelmében a Kat.-nak csak a rendkívüli intézkedések törvényi meghatározására kellene szorítkoznia. ${ }^{44}$ Szemben az előbbi álláspontokkal, Balázs István és Hoffman István nem utalt az alaptörvény-ellenességre: a szerző́k mindenfajta értékelés nélkül rögzítették, hogy a Kat. 44. \$c) pontja „[a]z Alaptörvény szabályát tágan értelmezve, annak szó szerinti értelmezéséhez képest, azt bővítve" nevesíti a humánjárványt. ${ }^{45}$

A fentiek alapján két kérdést kell feltenni: egyrészt azt, hogy a járvány(veszély) megfeleltethető-e a két alaptörvényi kategória (elemi csapás/ipari szerencsétlenség) valamelyikének, másrészt pedig azt, hogy miként értékelhető a Kat. 44. \$-a az Alaptörvény 53. cikk (1) bekezdésének fényében.

43 Szente, 2020, 133. o.

44 Mészáros, 2020, 66. o. Ezzel szemben a Kat. 44. \$-a azt mondja ki, hogy „[a] veszélyhelyzet az Alaptörvény 53. cikkében meghatározott olyan helyzet, amelyet különösen a következő események válthatnak ki: [...]”. Ebből a fogalmazásmódból az következik, hogy a Kat. lényegében definiálni kívánja a veszélyhelyzetet, méghozzá a kiváltó körülmények felsorolásával.

45 Balázs-Hoffman, 2020, 2. o. 
Ami az első kérdést illeti, az ipari szerencsétlenség értelemszerủen kizárható, így a kérdés arra egyszerűsödik le, hogy elemi csapásnak minősíthető-e a járvány(veszély). A kérdés nyelvi-szemantikai és jogi síkon is vizsgálható. A szemantikai szempontot illetően kiemelendő, hogy a témakört érintő közjogi-politikai diskurzusban mindkét irányú érvelésre találunk példát. Orbán Balázs, a Miniszterelnökség miniszterhelyettese szerint - utalva a bibliai tíz csapásra is, amelyek közül legalább három tömeges kór formájában jelentkezett a koronavírus-járvány egyértelmúen elemi csapásnak minősül. ${ }^{46}$ Mások viszont arra hívják fel a figyelmet, hogy a mértékadó lexikonok értelmében az elemi csapás „a természet erőinek (elemeinek) müködése folytán szokott bekövetkezni", ${ }^{7}$ illetve a járványokat általában a nemzetközi szakirodalomban sem sorolják a természeti katasztrófák közé. ${ }^{48}$

A nyelvi szempontú vizsgálódásnál természetesen nagyobb relevanciával bír a jogi megközelítés, azaz hogy az Alaptörvény és a Kat. összevetése során elemi csapásnak minősül-e a járvány(veszély). Itt viszont az a helyzet, hogy a Kat. 44. \$-a a járvány(veszély)t kifejezetten kiveszi az elemi csapások közül, és külön kategóriába (egyéb eredetú veszélyek) sorolja, vagyis a Kat. a járvány(veszély)t egyértelmúen nem tekinti elemi csapásnak. Megjegyzendő, hogy - amint Szente rámutat - az Alaptörvényből nem következik, hogy a humánjárványt ne lehetne az elemi csapások fogalmi körébe vonni, ${ }^{49}$ ugyanis - tehetjük hozzá - egy szó köznapi és jogszabályban definiált jelentéstartalma nem kell hogy szükségszerúen egybeessen..$^{50}$

Lehetséges-e olyan értelmezés, amely szerint a járvány(veszély) mégiscsak az elemi csapások közé tartozik? Álláspontunk szerint ez csak úgy lenne lehetséges, ha úgy érvelünk, hogy a Kat. 44. \$-a voltaképpen kettébontja az Alaptörvény elemicsapás-fogalmát, azaz az a) és a c) pont egyaránt az elemi csapást definiálja (pontosabban az elemi csapáshoz tartozó esetköröket sorolja fel) - előbbi manifeszt módon, utóbbi pedig mintegy kiegészítőleg. Ez esetben arról lenne szó, hogy az elemi csapásnak van egy tágabb [Alaptörvény 53. cikk (1) bekezdés] és egy szúkebb [Kat. 44. $\$$ a) pont] meghatározása, és a járvány(veszély) ugyan a Kat. elemicsapás-definíciójának nem felel meg, de az Alaptörvény alapján mégis lehet elemi csapásnak minősíteni.

Rátérve a másik kérdésre: vajon miként értékelhető a Kat. 44. \$-a az Alaptörvény 53. cikk (1) bekezdése fényében? Amint láttuk, az egyik narratíva az lehet, hogy a Kat.

46 Orbán, 2020.

47 A Pallas Nagy Lexikona. VI. kötet, Budapest: Pallas, 1994. 14. o. Idézi Szente, 2020, 117. o. Megjegyzendő, hogy az Alaptörvény hivatalos angol fordítása az elemi csapásra a natural disaster kifejezést használja. A szintén mértékadó Merriam-Webster-szótár szerint: „a sudden and terrible event in nature (such as a hurricane, tornado, or flood) that usually results in serious damage and many deaths". Elérhetô: www.merriam-webster. com/dictionary/natural\%20disaster (Letöltve: 2020 . november 10.).

48 Szente, 2020, 132. o.

49 Szente, 2020, 133. o.

50 A jogszabályszerkesztésről szóló 61/2009. (XII. 14.) IRM rendelet (Jszr.) 67. \$ (2) bekezdése értelmében egy fogalom jelentése az adott jogszabály alkalmazásában eltérhet a köznyelvi jelentésétől, illetve a más jogszabályban meghatározott jelentésétől (ez esetben értelmező rendelkezést kell alkalmazni). 
alkotmányellenesen "beleír” az Alaptörvénybe azzal, hogy egy kvázi taxatív felsorolást (elemi csapás, ipari szerencsétlenség) egyrészt ténylegesen is kibővít [a c) ponttal], másrészt pedig a további bővítés előtt is nyitva hagyja a lehetőséget [a 44 . $\$$ nyitó szövegrészében a különösen szó arra utal, hogy nemcsak az a)-c) pontok válthatják ki a veszélyhelyzetet]. A másik lehetséges értelmezés az lehet, hogy a Kat. 44. \$-a voltaképpen csak értelmezi és kifejti, részletezi az „elemi csapás vagy ipari szerencsétlenség” kifejezést. Ebben az esetben tehát az „elemi csapás vagy ipari szerencsétlenség” kifejezésre nem mint egy felsorolásra (pláne nem egy taxatív felsorolásra) kell tekinteni, hanem mint egy olyan általános tényállási elemre, amely törvényi szintû́ konkretizálást igényel. Ezen álláspont védelmében felhozható, hogy az Alaptörvény számos rendelkezését a jogszabályok töltik meg tartalommal, és voltaképpen ez esetben is az történik, hogy a Kat. részletezi, konkretizálja a veszélyhelyzetet kiváltó körülményeket. Ehhez kapcsolódóan érdemes felidézni a Kat. indokolását: „Az új terminológia szerinti veszélyhelyzet meghatározásakor felülvizsgálatra és tudományos eredmények felhasználásával kiegészítésre, korszerúsítésre került a lehetséges veszélyek köre." A jogalkotó itt a veszélyhelyzet korábbi törvényi meghatározására ${ }^{51}$ utal vissza, amely abból a szempontból is érdekes számunkra, hogy a Pvt. definíciója részben hasonlított a mostanira: „veszélyhelyzet [...] az élet- és vagyonbiztonságot vagy a környezetet veszélyeztetô természeti csapás, illetőleg ipari baleset okozta állapot, amelyet különösen a következő események válthatnak ki: [...]”. Az ezt követő felsorolásban megtalálható volt a „súlyos, több embernél halálos lefolyású tömeges megbetegedést előidéző kórokozó megjelenése", illetve több olyan körülmény (például ivóvíz szenynyeződése), amelyeket a Kat. jelenleg az egyéb eredetú veszélyek közé sorol. Ez alapján tehát megállapítható, hogy a Pvt. a járványt (noha nem ezt a kifejezést használta) kétséget kizáróan a természeti csapások közé sorolta. ${ }^{52}$ Amennyiben a jogalkotó a későbbiekben a Kat. megalkotásakor - is ehhez a megoldáshoz tartotta volna magát [ti. a járványra és a másik három, c) pont alatti körülményre nem állít fel egy „egyéb” kategóriát], úgy a Kat. és az Alaptörvény ütközése valószínúleg fel sem merült volna.

\section{A veszélyhelyzetet kihirdető rendeletek}

A veszélyhelyzet kihirdetéséről szóló 40/2020. (III. 11.) Korm. rendelet (a továbbiakban: Kihirdető r.) bevezető része három fordulatra tagolható, amelyek közül az első kettő érdemel alaposabb figyelmet:

51 A polgári védelemről szóló 1996. évi XXXVII. törvény (a továbbiakban: Pvt.) 2. \$ (2) bekezdés.

52 Megjegyzendő ugyanakkor, hogy az Alkotmány 35. $\$$ (1) bekezdés i) pontja és a Pvt. 2. $\$$ (2) bekezdése sem okvetlenül volt összhangban egymással, ugyanis az előbbi rendelkezés csak „az élet- és vagyonbiztonságot veszélyeztető elemi csapás"-ra használta a veszélyhelyzet kifejezést, míg a Pvt. ezt kiegészítette az ipari balesettel is. 


\begin{tabular}{|c|c|c|}
\hline & $\begin{array}{c}\text { A Kihirdető r. bevezető } \\
\text { szövege }\end{array}$ & Az Alaptörvény érintett rendelkezései \\
\hline 1. & $\begin{array}{l}\text { az Alaptörvény 53. cikk } \\
\text { (1) bekezdésében } \\
\text { meghatározott hatáskörében, }\end{array}$ & $\begin{array}{l}53 . \text { cikk } \\
\text { (1) A Kormány az élet- és vagyonbiztonságot veszélyeztető } \\
\text { elemi csapás vagy ipari szerencsétlenség esetén, valamint ezek } \\
\text { következményeinek az elhárítása érdekében veszélyhelyzetet } \\
\text { hirdet ki, és sarkalatos törvényben meghatározott rendkívüli } \\
\text { intézkedéseket vezethet be. }\end{array}$ \\
\hline 2. & $\begin{array}{l}\text { a } 2 \text {. és } 3 . \$ \text { tekintetében } \\
\text { az Alaptörvény 53. cikk } \\
\text { (2) bekezdésében } \\
\text { meghatározott eredeti } \\
\text { jogalkotói hatáskörében, }\end{array}$ & $\begin{array}{l}\text { 53. cikk } \\
\text { (2) A Kormány a veszélyhelyzetben rendeletet alkothat, } \\
\text { amellyel - sarkalatos törvényben meghatározottak szerint - } \\
\text { egyes törvények alkalmazását felfüggesztheti, törvényi ren- } \\
\text { delkezésektől eltérhet, valamint egyéb rendkivüli intézkedéseket } \\
\text { hozhat. }\end{array}$ \\
\hline 3. & $\begin{array}{l}\text { az Alaptörvény 15. cikk } \\
\text { (1) bekezdésében meghatá- } \\
\text { rozott feladatkörében eljárva } \\
\text { a következőket rendeli el: }\end{array}$ & $\begin{array}{l}\text { 15. cikk } \\
\text { (1) A Kormány a végrehajtó hatalom általános szerve, amelynek } \\
\text { feladat- és hatásköre kiterjed mindarra, amit az Alaptörvény } \\
\text { vagy jogszabály kifejezetten nem utal más szerv feladat- és } \\
\text { hatáskörébe. [...] }\end{array}$ \\
\hline
\end{tabular}

4. táblázat

A Kihirdetőr r.és az Alaptörvény kapcsolata

Forrás: a szerző saját összeállítása

Az 1. fordulat a veszélyhelyzet kihirdetését lehetővé tevő alaptörvényi rendelkezésre utal, méghozzá úgy, hogy a fordulatban a „hatáskör” szó előtt nincs jelző. A Jogtár segítségével megállapítható, hogy ezzel a megoldással kizárólag a veszélyhelyzettel kapcsolatos kormányrendeletek esetén találkozhatunk. A 2. fordulat viszont már kifejezetten utal az (eredeti) jogalkotói hatáskörre, de csak a 2-3. \$ vonatkozásában. Jogalkotástani szempontból mindez tehát azt jelenti, hogy a veszélyhelyzet kihirdetése voltaképp nem egy eredeti jogalkotói hatáskörben meghozott aktusnak tekinthető. ${ }^{53}$

Ezt követően tanulságos közelebbről is megvizsgálni a Kihirdető r. 1. \$-át:

„1. \$ A Kormány az élet- és vagyonbiztonságot veszélyeztető tömeges megbetegedést okozó humánjárvány következményeinek elhárítása, a magyar állampolgárok

53 Itt érdemes feltenni azt a kérdést, hogy miként alakult volna a Kihirdető $r$. bevezetô része, ha a Kormány úgy döntött volna, hogy ebben a rendeletben kizárólag a veszélyhelyzet kihirdetéséről rendelkezik, és minden további (rendkívüli) intézkedést további rendeletekben hoz meg. Ebben az esetben a Kihirdető r. - elvileg egy olyan kormányrendelet lett volna, amelyet nem is eredeti, és nem is származékos jogalkotói jogkörében hozott volna meg a Kormány. 
egészségének és életének megóvása érdekében Magyarország egész területére veszélyhelyzetet hirdet ki."

Most pedig idézzünk fel egy korábbi, a dunai árvíz miatt veszélyhelyzetet kihirdető 2013-as kormányrendeletet: ${ }^{54}$

„1. \$ A Kormány Győr-Moson-Sopron megye és Komárom-Esztergom megye területére, [...] árvízi veszély miatt a katasztrófavédelemről és a hozzá kapcsolódó egyes törvények módosításáról szóló 2011. évi CXXVIII. törvény (a továbbiakban: Kat.) 44. \$a) pont aa) alpontja alapján veszélyhelyzetet hirdet ki."

A két szakaszt összevetve szembeötlő különbség, hogy a 2013-as rendelet kifejezetten (úgynevezett merev hivatkozással) utal a Kat. azon rendelkezésére, amely akkor lehetővé tette a veszélyhelyzet kihirdetését..$^{55}$ (Amennyiben a többi veszélyhelyzetet kihirdetô kormányrendeletet vizsgáljuk, ugyanezt tapasztaljuk.) Ezzel szemben a Kihirdető r. explicit módon nem hivatkozik a Kat.-ra, noha logikus lenne az az elvárás, hogy a különböző veszélyhelyzetek kihirdetésére hasonló formában kerüljön sor.

Figyelmet érdemel továbbá „az élet- és vagyonbiztonságot veszélyeztető tömeges megbetegedést okozó humánjárvány" fordulat, ami abból a szempontból érdekes, hogy mintegy ötvözi az Alaptörvény 53. cikk (1) bekezdésének kifejezését („élet- és vagyonbiztonságot veszélyeztető”) a Kat. 44. \$ ca) alpontjának kifejezésével („tömeges megbetegedést okozó humánjárvány”). Mészáros álláspontja szerint „[a] veszélyhelyzetet kihirdető kormányrendelet tehát nem az Alaptörvényre, hanem a Kat.-ra hivatkozással rendelte el a különleges jogrendet [...] ${ }^{56}$ Ez a meglátás azonban nem teljesen pontos, hiszen a Kihirdető r. formailag egyértelmúen az Alaptörvényre hivatkozik, viszont - és ennyiben egyet tudunk érteni a szerzővel - az 1. \$-ban megjelenik a Kat. kapcsolódó rendelkezése („tömeges megbetegedést okozó humánjárvány") is - ám mindez a Kat.-ra való hivatkozás nélkül. Összességében tehát megállapítható, hogy mintha a jogalkotó is igyekezett volna „elkenni” a veszélyhelyzet kihirdetésének alapjait, ugyanis abban utalt is, meg nem is a Kat.-ra. [Mindez akár azzal is összefügghet, hogy maga a jogalkotó is tudatában volt annak, hogy erősen aggályos a Kat. 44. \$c) pontja és az Alaptörvény 53. cikk (1) bekezdésének összhangja, és ezzel a felemás megoldással kívánta a helyzetet orvosolni.]

Ezek alapján egy újabb kérdés merül fel: vajon lehet-e úgy érvelni, hogy a Kormány voltaképpen közvetlenül az Alaptörvényből vezette le a veszélyhelyzet kihirdetésének lehetőségét,

54 Veszélyhelyzet kihirdetéséről és az ennek során teendő intézkedésekről szóló 177/2013. (VI. 4.) Korm. rendelet. 55 Kat. 44. \$a) pont aa) alpont: „árvízvédekezés során, ha az előrejelzések szerint az áradó víz az addig észlelt legmagasabb vízállást megközelíti és további jelentős áradás várható, vagy elháríthatatlan jégtorlasz keletkezett, vagy töltésszakadás veszélye fenyeget".

56 Mészáros, 2019, 66. o. 
és ez esetben nincs is szükség a Kat. 44. \$-ára? (Ebből a szempontból különösen érdekes Mészáros - fentebb már hivatkozott - felvetése, miszerint a Kat.-nak eleve nincs felhatalmazása a veszélyhelyzetet előidéző körülmények pontos meghatározására, ugyanis - állítja a szerző - a Kat. az Alaptörvény alapján „csak a rendkívüli intézkedések törvényi meghatározására szorítkozhat". $)^{57} \mathrm{~A}$ Kihirdetô r. bevezetô része alapján úgy túnik, mintha a jogalkotó formálisan kikapcsolta volna a Kat.-ot, és a járványt olyan, az élet- és vagyonbiztonságot veszélyeztetó elemi csapásnak tekintette, amely alapot ad a veszélyhelyzet kihirdetésére.

2020. novemberben ismételten veszélyhelyzetet hirdetett a Kormány. A veszélyhelyzet kihirdetésérôl szóló 478/2020. (XI. 3.) Korm. rendelet (a továbbiakban: 2 . Kihirdető r.) bevezető részének első fordulata kiegészült a „figyelemmel a katasztrófavédelemről és a hozzá kapcsolódó egyes törvények módosításáról szóló 2011. évi CXXVIII. törvény 51/A. \$-ára" szövegrésszel, ${ }^{58}$ azaz a jogalkotó immár formálisan is összekötötte a kormányrendeletet és a Kat.-ot. Csakhogy a Kat.-ra való hivatkozás továbbra sem problémamentes, ugyanis az nem a veszélyhelyzetet kiváltó okok valamelyikére [konkrétan a 44 . $\$ c$ ) pont ca) alpontjára] történik, hanem arra az 51/A. \$-ra, amely a humánjárvány miatt már kihirdetett veszélyhelyzetben meghozható rendkívüli intézkedéseket tartalmazza. Álláspontunk szerint a kihirdetés jogalapját illetôen sokkal tisztább helyzetet teremtettek a 2020 elôtti veszélyhelyzeteket bevezető rendeletek (mint például a fentebb hivatkozott 2013-as árvizes rendelet), azonban a jogalkotó a 2 . Kihirdető r. esetén nem (sem) ezt az utat választotta, ami összefügghet a Kat. 44. \$c) pontjának és az Alaptörvény 53. cikk (1) bekezdésének problémás kapcsolatával.

\section{Az Alaptörvény 53. cikkének belső koherenciája}

A következőkben az Alaptörvénynek a veszélyhelyzetet szabályozó 53. cikkét vesszük számba, és amellett érvelünk, hogy a rendelkezések szövegezése nem egyértelmú, és a cikk belső koherenciája is megkérdőjelezhető. Annak érdekében, hogy jobban kirajzolódjon a Kormány veszélyhelyzeti cselekvési jogosultsága, az 53. cikk (1)-(2) bekezdésében aláhúzással kiemeltük, és egyben $[A]-[D]$ betúkkel jelöltük, hogy az alaptörvényi rendelkezések milyen aktusokra adnak lehetőséget a Kormánynak:

„(1) A Kormány az élet- és vagyonbiztonságot veszélyeztető elemi csapás vagy ipari szerencsétlenség esetén, valamint ezek következményeinek az elhárítása érdekében [A] veszélyhelyzetet hirdet ki, és sarkalatos törvényben meghatározott $[B]$ rendkívüli intézkedéseket vezethet be.

57 Mészáros, 2019, 66. o. Vö.: Alaptörvény 54. cikk (4) bekezdés: „A különleges jogrendben alkalmazandó részletes szabályokat sarkalatos törvény határozza meg.".

58 A Kat. 2020. júniusban kiegészült egy új szakasszal (és egyben alcímmel: A Kormány rendkivüli intézkedései tömeges megbetegedést okozó humánjárvánnyal összefüggő veszélyhelyzetben). 
(2) A Kormány a veszélyhelyzetben [C] rendeletet alkothat, amellyel - sarkalatos törvényben meghatározottak szerint - egyes törvények alkalmazását felfüggesztheti, törvényi rendelkezésektől eltérhet, valamint $[D]$ egyéb rendkívüli intézkedéseket hozhat. ${ }^{.59}$

Az [A]-val jelölt aktus („veszélyhelyzetet hirdet ki”) magát a veszélyhelyzet kihirdetését jelenti. Amint Szente rámutat, az Alaptörvény szövege nem rendelkezik arról, hogy a veszélyhelyzetet a Kormánynak milyen formában kell kihirdetnie. ${ }^{60}$ Álláspontja szerint viszont az alkotmányossági és a joglogikai szempontok alapján is igazolható, hogy a rendeleti forma az adekvát. (Ehhez hozzátehetjük, hogy eddig valamennyi veszélyhelyzet kormányrendeletben került kihirdetésre.)

A [B]-vel jelölt aktus („rendkívüli intézkedéseket vezethet be”) két szempontból is problémásnak minősül. Egyrészt nem teljesen világos, hogy az ez alapján meghozott intézkedések csak a [C]-vel jelölt kormányrendelet(ek) keretében vezethetők-e be. Másrészt tisztázatlannak túnik a $[B]$ és a $[D]$ aktusok viszonya, hiszen meglehetősen hasonló kifejezésekről van szó („rendkívüli intézkedéseket vezethet be” vs. „rendkívüli intézkedéseket hozhat” - ráadásul a „sarkalatos törvényben meghatározottak szerint” kitétel mindkét aktusra vonatkozik).

A [D]-vel jelölt aktus („egyéb rendkívüli intézkedéseket hozhat”) esetén az okozhat értelmezési problémát, hogy erre a fordulatra is vonatkoztathatók-e a (2) bekezdésben körülírt rendelet attribútumai, vagyis az „egyéb rendkívüli intézkedéseket hozhat” csak a megalkotott rendelet keretén belül értelmezhető-e (ez esetben a fordulat illeszkedik az „amellyel” szót követő felsorolásba, annak egy elemét képezi). A másik interpretáció az lehetne, hogy a fordulat elválik a rendeletre utaló szövegrésztôl - ez esetben az értelmezés a következő lenne: „A Kormány a veszélyhelyzetben [...] egyéb rendkívüli intézkedéseket hozhat” (ti. rendeletalkotás nélkül is). Bár első látására is az első értelmezés túnik logikusnak, a Kat. 45. \$ (1) bekezdésére figyelemmel egyértelmú lesz a válasz: „Veszélyhelyzetben, a katasztrófa elhárításához szükséges mértékben és területen a Kormány rendeleti úton a 47-48. \$ szerinti rendkívüli intézkedéseket vezetheti be, illetve a 49-51. \$ szerinti rendkívüli intézkedések bevezetésével ezek végrehajtására adhat felhatalmazást." A Kat. tehát kifejezetten utal a rendeleti útra, vagyis a fentiek közül az első értelmezés a helyes. [Átláthatóbb lenne a helyzet, ha az 53. cikk (2) bekezdésében a felsorolás három elemét külön pontokba szedné az alkotmányozó. $]^{61}$ Mindezek alapján a [D] nem különálló aktus, hanem a [C] része, azaz a rendkívüli intézkedések meghozatala a rendeletalkotás révén lehetséges. (Mindez azt is jelenti, hogy az egyes törvények alkalmazásának felfüggesztése, valamint a törvényi rendelkezésektől

59 Megjegyzendő, hogy az 53. cikk (2) bekezdésében foglaltak lényegében változatlan formában megtalálhatók három másik különleges jogrendnél is \{megelőző védelmi helyzet [51. cikk (4) bekezdés]; terrorveszélyhelyzet [51/A. cikk (4) bekezdés]; váratlan támadás [52. cikk (3) bekezdés]\}.

60 Szente, 2020, 126. o.

61 Vö.: Jszr. 46. \$ (1) bekezdés. 
való eltérés is rendkívüli intézkedésnek minősülnek, de ezeken felül egyéb rendkívüli intézkedések is léteznek.)

Visszatérve a [B] és a [D] aktus elhatárolására, itt arról van szó, hogy ez a két fordulat voltaképpen ugyanazt az aktust jelenti-e, vagy sem. Az igenlő válasz mellett szól az a tény, hogy a [B] aktus is a sarkalatos törvényben meghatározott rendkívüli intézkedésnek minősül, akárcsak a [D] (már amennyiben „a [D] aktus a [C] aktus része” következtetésünk helyes). Viszont a $[B]=[D]$ következtetés erejét gyengíti, hogy az alkotmányozó valamilyen okból mégiscsak két külön bekezdésben említi ezeket, amelyek közül az (1) bekezdés a veszélyhelyzet kihirdetését szabályozza, a (2) pedig a veszélyhelyzet alatti rendeletalkotást. Vajon mi indokolta, hogy ugyanazon hatáskör (ti. a Kormány veszélyhelyzetben rendkívüli intézkedést vezethet be/hozhat) egymást követően kétszer - hasonló kontextusban, de némileg eltérő fogalmazásmóddal - is nevesítve legyen? Ha $[B] \neq[D]$, akkor viszont felmerül a kérdés, hogy létezik-e olyan - sarkalatos törvényben meghatározott - rendkívüli intézkedés, amelynek a bevezetése nem igényel rendeletalkotást. A Kormány a veszélyhelyzet kihirdetését követően számos - jogszabálynak értelemszerủen nem minősülő - kormányhatározatot is hozott a járvány kezelésével összefüggésben, azonban ezek csak közvetve köthetők össze a Kat.-tal mint irányadó sarkalatos törvénnyel. Ezenfelül - elméletileg - egy olyan értelmezés is elképzelhető, hogy a $[B]=[D]$, viszont a $[B]$-vel jelölt aktusokat a veszélyhelyzet kihirdetésével egyidejüleg vezetheti be a Kormány, és ezekre - lévén hogy nem a (2) bekezdés hatálya alá tartoznak - nem vonatkozik a 15 napos „élettartam”.

Összességében a legvalószínúbb - és egyben a leglogikusabb - értelmezés az, hogy $[B]=[D]$, csak éppen az alkotmányozó már az (1) bekezdésben jelezni kívánta, hogy veszélyhelyzetben a Kormány - sarkalatos törvényben meghatározott - rendkívüli intézkedéseket vezethet be. Ez azonban abból a szempontból felesleges - és egyben némileg félrevezetô is -, hogy a (2) bekezdés részletesebben is szabályozza a rendkívüli intézkedések meghozatalát.

\section{A meghosszabbítás kérdései}

Ahogyan maga a veszélyhelyzet, úgy annak meghosszabbítása sem példa nélküli a magyar közjogtörténetben. ${ }^{62}$ A 2020 előtt kihirdetett veszélyhelyzeteket tekintve megállapítható, hogy az Országgyưlés hét alkalommal járult hozzá ezek meghosszabbításához.63 A hozzájárulás mindegyik esetben országgyưlési határozat formájában történt, és határozott időre szólt (az árvíz miatti veszélyhelyzeteknél a hosszabbítás időtartama hozzávetőlegesen

62 A meghosszabbítás közjogi megoldásaira lásd: Ungvári-Hojnyák, 2020. Pontosításképp megjegyzendő, hogy ténylegesen nem magát a veszélyhelyzetet kell/lehet meghosszabbítani, hiszen a veszélyhelyzet időtartama a Kormány döntésétől függ; ehelyett a veszélyhelyzeti kormányrendeletek hatálya szorul meghosszabbításra.

63 Pontosításképp megjegyzendő, hogy az Alaptörvény hatálybalépése előtti veszélyhelyzetek esetén az Országgyúlés engedélyezte a veszélyhelyzet meghosszabbítását. 
40-50 nap volt, míg az iszapkatasztrófánál alkalmanként megközelítőleg 3 hónap). A járvány miatti veszélyhelyzet meghosszabbításának egyik újdonsága az volt, hogy az nem OGY határozatban, hanem törvényben történt (a koronavírus elleni védekezésről szóló 2020. évi XII. törvény - a továbbiakban: Kevtv.). Mivel sem a korábbi Alkotmány, sem az Alaptörvény nem határozta/határozza meg a meghosszabbítás formátumát, mindkét megoldás elfogadható, hiszen ahogyan a törvény, úgy az OGY határozat is normatív aktusnak tekinthető.

A következőkben azt járjuk körül, hogy milyen értelmezési problémák merül(het)tek fel a veszélyhelyzet - pontosabban a veszélyhelyzeti kormányrendeletek hatályának - meghoszszabbítása során. Kiindulópontként térjünk vissza a tanulmány előző pontjában alkalmazott [A]-[D] felosztáshoz. Álláspontom szerint az, hogy a [B] aktus ugyanaz-e, mint a [D], komoly relevanciával bír az adott intézkedés hatálya szempontjából. Az Alaptörvény 53. cikk (3) bekezdése ugyanis a következőképp rendelkezik: „A Kormány (2) bekezdés szerinti rendelete tizenöt napig marad hatályban, kivéve, ha a Kormány - az Országgyúlés felhatalmazása alapján - a rendelet hatályát meghosszabbítja." Ebből a rendelkezésből egyértelmúen az következik, hogy az $[A]$ és a $[B]$ aktusok hatályának meghosszabbításához nincs szükség az Országgyúlés felhatalmazására [hiszen azok nem minősülnek a (2) bekezdési rendeletnek], vagyis magának a kihirdetett veszélyhelyzetnek a meghosszabbításához nem szükséges az Országgyuulés felhatalmazása/hozzájárulása. Hasonló a helyzet a [B]-vel jelölt aktusoknál, azaz - elvileg - a sarkalatos törvényben meghatározott, már bevezetett rendkívüli intézkedések hatálya sem függ az Országgyúléstől.

A korábbi - de már Alaptörvény utáni - országgyưlési meghosszabbítások a következő fordulatot tartalmazták:64

„Az Országgyúlés az Alaptörvény 53. cikk (3) bekezdése alapján felhatalmazza a Kormányt, hogy a veszélyhelyzet kihirdetéséről és az ennek során teendő intézkedésekről szóló [...] Korm. rendelet hatályát legfeljebb [...]-ig meghosszabbítsa, [...]."

Ezzel szemben a Kevtv. így fogalmazott:

„3. \$ (1) Az Országgyúlés az Alaptörvény 53. cikk (3) bekezdése alapján felhatalmazza a Kormányt, hogy a veszélyhelyzetben az Alaptörvény 53. cikk (1) és (2) bekezdése szerinti kormányrendeletek hatályát a veszélyhelyzet megszűnéséig meghosszabbítsa.

$[\ldots]$

64 Lásd például: a 2013. június 4-én kihirdetett veszélyhelyzet meghosszabbításához történő hozzájárulásról szóló 44/2013. (VI. 12.) OGY határozat 1. a) pontját. 
(3) Az Országgyưlés a Rendelet hatálybalépését követően e törvény hatálybalépéséig megalkotott, (1) bekezdés szerinti kormányrendeleteket megerősíti."

Kérdéses, hogy miért volt szükség arra, hogy a felhatalmazás az 53. cikk (1) bekezdése szerinti - azaz a veszélyhelyzetet kihirdető, 40/2020. (III. 11.) számú - kormányrendeletre is kiterjedjen? Álláspontunk szerint ez két - egymással összefüggő - szempontból is felesleges: egyrészt ha a Kormány - az Alaptörvényben meghatározott körülmények esetén, de lényegében saját belátása alapján - dönthet a veszélyhelyzet kihirdetéséről, akkor ebből az következik, hogy a veszélyhelyzet megszüntetéséről is a Kormány dönt. Másrészt az Alaptörvény az 53. cikk (3) bekezdésében említett 15 napos szabályt csak a (2) bekezdés szerinti rendeletekre [C] vonatkoztatja, amiből az következik, hogy az (1) bekezdés szerinti rendelet [A] hatályát nem érinti a 15 nap lejárta.

Kiemelendő, hogy az Országgyúlés részére benyújtott T/9790. számú törvényjavaslat eredeti változata ${ }^{65}$ még így fogalmazott:

„3. \$ (1) Az Országgyưlés az Alaptörvény 53. cikk (3) bekezdése alapján felhatalmazza a Kormányt, hogy

a) a Rendelet [vagyis a Kihirdetőr. rendelet-H. A.] 2. \$-a és 3. \$-a, valamint

b) a veszélyhelyzetben az Alaptörvény 53. cikk (1) és (2) bekezdése szerinti kormányrendeletek hatályát a veszélyhelyzet megszűnéséig meghosszabbítsa."

Ez a szövegváltozat tehát a Kihirdető r.-et - pontosabban annak 2-3. \$-át - leválasztotta volna a többi veszélyhelyzeti rendeletről. De miért esett a 2-3. \$ „külön elbírálás” alá? Ennek megválaszolásához szükséges felidézni a Kihirdető r. szövegét:

„1. A veszélyhelyzet kihirdetése

1. \$A Kormány az élet- és vagyonbiztonságot veszélyeztető tömeges megbetegedést okozó humánjárvány következményeinek elhárítása, a magyar állampolgárok egészségének és életének megóvása érdekében Magyarország egész területére veszélyhelyzetet hirdet ki.

2. § (1) A Kormány a veszélyhelyzet elhárításáért felelős kormánytagként a miniszterelnököt jelöli ki.

(2) A miniszterelnököt az (1) bekezdés szerinti feladatának ellátásában Koronavírus-járvány Elleni Védekezésért Felelős Operatív Törzs segíti.

3. \$ (1) A veszélyhelyzettel kapcsolatos rendkívüli intézkedésekről külön kormányrendeletek rendelkeznek.

65 Elérhetô: www.parlament.hu/irom41/09790/09790.pdf(Letöltve: 2020. november 10.). 
(2) A Kormány a veszélyhelyzet fennállásának szükségességét folyamatosan felülvizsgálja.

(3) A Kormány az állampolgárok együttmủködését kéri a különleges jogrenddel járó intézkedések végrehajtásában.

2. Záró rendelkezések

4. \$ Ez a rendelet a kihirdetése napján 15 órakor lép hatályba."

Amint látható, az 1. $\$$ a veszélyhelyzet kihirdetésének tényét tartalmazta. Ez a rendelkezés volt az egész veszélyhelyzeti jogalkotás magja, hiszen ez a szakasz vezette be a különleges jogrendet. Ehhez képest a 2-3. \$ már "többletrendelkezéseket” tartalmazott, amelyek a $[B]$ vagy a $[D]$ szerinti aktusoknak minősülnek.

Ez a rendelet egyfajta hibrid rendeletnek minősül, hiszen egyszerre tartalmazta a veszélyhelyzet kihirdetésének tényét, valamint bizonyos további (rendkívüli?) intézkedések is ebben kerültek bevezetésre. ${ }^{66} \mathrm{~A}$ hibrid jelleg abból a szempontból érthető megoldás, hogy a jogalkotó a veszélyhelyzet kihirdetésével egyidejûleg bizonyos rendkívüli intézkedéseket is be kíván vezetni, hiszen önmagában a veszélyhelyzet deklarálása aligha alkalmas a probléma kezelésére. ${ }^{67}$ Bár bizonyos szempontból furcsa megoldásnak túnhet, de álláspontunk szerint dogmatikailag is tisztább helyzetet eredményezett volna, ha a Kormány egy külön rendeletet szentelt volna a veszélyhelyzet kihirdetésének, és ez a kihirdető jogszabály semmilyen további rendelkezést nem tartalmazott volna; a további (rendkívüli) intézkedések pedig külön kormányrendeletekbe kerültek volna. ${ }^{68}$

Úgy véljük, hogy a törvényjavaslat benyújtója maga is észlelte a Kihirdetô r. hibrid jellegét, és egyúttal annak is tudatában volt, hogy szabályozástechnikai szempontból nem szabad a rendeletet egységesként kezelni. A 2-3. \$ leválasztása azt szolgálta volna, hogy magának a veszélyhelyzetnek a meghosszabbításához ne kelljen az Országgyưlés hozzájárulását kérni. A Kevtv.-be végül ez a rendelkezés került:

„3. \$ (1) Az Országgyúlés az Alaptörvény 53. cikk (3) bekezdése alapján felhatalmazza a Kormányt, hogy a veszélyhelyzetben az Alaptörvény 53. cikk (1) és (2) bekezdése szerinti kormányrendeletek hatályát a veszélyhelyzet megszűnéséig meghosszabbítsa."

Ebben a rendelkezésben az Országgyưlés az 53. cikk (1) és (2) bekezdése szerinti kormányrendeletek hatályának meghosszabbításához adta meg a felhatalmazását. A (2) cikk szerinti

66 Vö.: Salgó, 2020, 14-15. o.

67 Megjegyzendő, hogy a 2. Kihirdető r. hibrid jellege már a formai tagolásban is érződik, ugyanis a jogalkotó immár külön-külön alcímet szentelt a veszélyhelyzet kihirdetésének, valamint A koronavírus-világjárvány következményeinek elhárításával összefüggő szabályoknak.

68 Ezzel ellentétes érvelésre lásd: Mészáros, 2019, 67. 0. 
rendeletek - amelyek részben már korábban meg lettek alkotva, részben pedig késôbb kerültek megalkotásra - egyértelmúen korlátozott (15 napos) hatályú rendeletek.

Más a helyzet az (1) bekezdés szerinti rendeletekkel/rendelkezésekkel, ugyanis az már egyáltalán nem világos, hogy ezen rendelet(ek) esetén miként értelmezendő a meghosszabbítás. Amint fentebb láttuk, az 53. cikk (1) bekezdése két aktust foglal magába: a veszélyhelyzet kihirdetését $[A]$ és a rendkívüli intézkedések bevezetését [B]. Az előbbi biztosan nem igényel meghosszabbítást, hiszen - az Alaptörvény 54. cikk (3) bekezdése értelmében - a különleges jogrendet a különleges jogrend bevezetésére jogosult szerv megszünteti, ha kihirdetésének feltételei már nem állnak fenn - vagyis a 15 napos korlát magára a veszélyhelyzetre nem vonatkozik/vonatkozott. Annak, hogy a jogalkotó mégis szükségesnek érezte az (1) bekezdés szerinti rendeletek hatályának meghosszabbítását, az lehetett az oka, hogy a [B]-vel jelölt aktusok sorsát is figyelembe kívánta venni. Ezt alátámasztandó, nézzük meg a T/9790/15. számú összegző módosító javaslatot, ${ }^{69}$ amely változtatott a törvényjavaslat szövegén. Az iromány indokolása így szól:

„Tekintettel arra, hogy az ellenzéki pártok nem támogatták a határozati házszabályi rendelkezésektől való eltérésre vonatkozó kezdeményezést, így a törvényjavaslatot az Országgyuúlés 2020. március 24-én nem fogadhatta el. E tényre tekintettel a Kormánynak az emberek életének védelmében és a veszélyhelyzet negatív hatásainak mérséklése érdekében a járványügyi helyzetre tekintettel a törvényjavaslat hatálybalépését megelőzően hozott azon gyors és hatékony intézkedései, amelyek hatályát az Országgyưlés felhatalmazása hiányában a Kormány nem tudja meghosszabbítani, azok hatályukat vesztik. Emiatt a veszélyhelyzet kihirdetéséről szóló 40/2020. (III. 11.) Korm. rendelet 2. \$-a és 3 . \$-a is hatályát veszti a törvényjavaslat várható elfogadását és hatálybalépését megelőzően. Emiatt a törvényjavaslatban azokat a rendelkezéseket és szövegrészeket, amelyek a veszélyhelyzet kihirdetéséről szóló 40/2020. (III. 11.) Korm. rendelet 2. \$-ára és 3. \$-ára utalnak, el kell hagyni."

A jogalkotó tehát úgy vélte, hogy - az Országgyúlés meghosszabbításra való felhatalmazása hiányában - a Kihirdető r. 2-3. \$-a 15 nap után hatályát fogja veszíteni. Ez be is következett; a Jogtár a rendelet 2020. március 26-tól hatályos szövegváltozatában a következő megjegyzést füzi a 2-3. \$-hoz: „Hatályon kívül helyezve: Magyarország Alaptörvénye 53. cikk (3) bekezdése alapján. Hatálytalan: 2020. III. 26-án 15 órától."7o (Innentől kezdve csak a veszélyhelyzetet kihirdető 1 . \$ maradt hatályban.) Milyen következtetéseket lehet levonni a jogalkotó ezen gondolatmenetéből?

69 Elérhetô: www.parlament.hu/irom41/09790/09790-0015.pdf (Letöltve: 2020. november 10.).

70 Egyes álláspontok szerint ez volt az első eset, hogy egy jogszabály az Alaptörvény alapján automatikusan hatályát vesztette (Salgó, 2020, 14. o.). 
Egyrészt azt, hogy a jogalkotó mégiscsak különbséget tett a [B] és a $[D]$ aktusok között, hiszen ha a $[B]$ ugyanazt jelentené, amit a $[D]$, akkor a törvényben elegendő lett volna csak az 53. cikk (2) bekezdése szerinti kormányrendeletekre utalni. Viszont ha $[B] \neq[D]$, és azt az értelmezést követjük, hogy az Alaptörvény 53. cikk (1) bekezdése nemcsak a veszélyhelyzet kihirdetésére jogosítja fel a Kormányt, hanem egyúttal arra is, hogy sarkalatos törvényben meghatározott rendkívüli intézkedéseket vezessen be, akkor megint csak fel kell hívnunk a figyelmet arra, hogy az 53. cikk szerkezetéből - ahogyan arra már szintén utaltunk - az következik, hogy ezen utóbbi rendkívüli intézkedések 15 napon túli hatályának fenntartásához nem szükséges a meghosszabbítás. Kérdés, hogy a Kihirdető r. 2-3. \$-a ilyen sarkalatos törvényben meghatározott rendkívüli intézkedéseknek minősül-e.

Ami a 2. \$-t illeti, a Kat. a veszélyhelyzetre vonatkozó sajátos irányítási szabályok között nem tartalmaz kifejezett rendelkezést arra, hogy a veszélyhelyzet esetén annak elhárításáért felelős kormánytagot kell vagy lehet kijelölni, ${ }^{71}$ azonban a Kormánynak a veszélyhelyzetben játszott központi szerepére tekintettel teljességgel nyilvánvaló, hogy kijelölhető a veszélyhelyzet elhárításáért felelős kormánytag. A Koronavírus-járvány Elleni Védekezésért Felelős Operatív Törzs létrehozásával kapcsolatban kiemelendő, hogy azt nem a Kihirdető r. hozta létre, ugyanis a Törzs már több mint egy hónappal korábban felállításra került (méghozzá nem is kormányrendeleti, hanem - helyesen - "csak” kormányhatározati szinten). ${ }^{72} \mathrm{~A} 3 . \$$ (1) bekezdésében foglalt rendelkezésnek nincs különösebb normatív tartalma, és az abban foglaltak az Alaptörvény 53. $\$(2)$ bekezdése értelmében egyébként is magától értetődők. A (2) bekezdés szintén triviális rendelkezést tartalmaz, amely a rendeltetésszerú joggyakorlás elvéből is következik. A (3) bekezdés - már csak a fogalmazásmódja alapján is - szintén csak szimbolikus jellegû rendelkezésnek minősíthető.

A 2-3. \$ tartalmát elemezve tehát arra a következtetésre juthatunk, hogy ezek a rendelkezések nem minősülnek sarkalatos törvényben meghatározott rendkívüli intézkedéseknek. Egyrészt azért nem, mert a Kat. nem utal ilyen intézkedésekre, másrészt azért sem, mert ezek a rendelkezések/intézkedések korlátozott normatív hatállyal bírnak, és a rendkívüliségük is megkérdőjelezhető. Harmadrészt pedig pontosan az iménti rendelkezések egyike, a 3. \$ (1) bekezdése szögezi le, hogy a veszélyhelyzettel kapcsolatos rendkívüli intézkedésekről külön kormányrendeletek rendelkeznek - ez a megfogalmazás viszont arra enged következtetni, hogy a Kihirdetô r. nem ilyen rendkívüli intézkedéseket tartalmazó rendelet.

Összességében tehát nem látunk olyan érvet, amely amellett szólna, hogy ezen rendelkezések hatályának meghosszabbítására garanciális okokból szükség lett volna az Ország-

71 A Kat. veszélyhelyzetre vonatkozó sajátos irányítási szabályok között egyedül a miniszteri biztos kinevezését teszi lehetővé: „Amennyiben a veszélyhelyzet több megyét érint, vagy ha a katasztrófa elhárítása érdekében ez szükséges, a katasztrófák elleni védekezésért felelős miniszter - legfeljebb a veszélyhelyzet fennállásáig miniszteri biztost nevezhet ki." [46. $\$$ (1) bekezdés].

72 A Koronavírus-járvány Elleni Védekezésért Felelős Operatív Törzs felállításáról szóló 1012/2020. (I. 31.) Korm. határozat. 
gyưlésre. ${ }^{73}$ Ezek alapján úgy véljük, hogy a 15 napos határidő lejártának a Kihirdető r. 2-3. \$ hatályát nem kellett volna érintenie. ${ }^{74}$

\section{7. Összegzés}

Bár a fentiekben alapvetően kritikus módon, a problémákra rávilágítva vizsgáltuk a veszélyhelyzet közjogi és jogalkotási problémáit, természetesen azzal is tisztában vagyunk, hogy a kormányzatnak ezekben a helyzetekben napok vagy órák alatt kellett - esetenként példa nélküli - döntéseket hoznia, a jogalkotónak pedig ezeket a döntéseket meglehetősen gyors ütemben kellett jogi formába öntenie, aminek következtében bizonyos jogalkotási megfontolások szükségképpen háttérbe szorultak. A magunk részéról egyet tudunk érteni Tordai Csabával, aki szerint „rendkívüli helyzetekben a jog normativitása nem korlátozhatja az állam hatékony cselekvését: egyetlen emberélet sem kerülhet veszélybe rendkívüli jogrendre okot adó körülmények miatt csak azért, mert a normákat megfogalmazó jogalkotók nem látták előre az összes lehetséges veszélyt és szükséges intézkedést".75 Ebből a szempontból különösen figyelemre méltó az Igazságügyi Minisztérium jogszabály-előkészítés összehangolásáért és a közjogi jogalkotásért felelős helyettes államtitkárának az az (ön)kritikus megjegyzése, miszerint „a katasztrófavédelmi törvényben szereplő veszélyhelyzeti szabályokat nem járványhelyzet kezelésére írták", és a magyar jogrendszer nem volt felkészülve a koronavírus-járványból fakadó bizonytalan helyzet kezelésére. ${ }^{76}$

A 2020. őszi fejlemények nyomán megállapítható, hogy egyelőre még nem lehet múlt időben beszélni a veszélyhelyzetről, így a veszélyhelyzeti szabályozási rendszer múködésének teljes körủ kiértékelése is várat magára. Ugyanakkor az - már csak a fentebb hivatkozott helyettes államtitkári álláspont alapján is - vitathatatlan, hogy a szabályozás felülvizsgálatra szorul. ${ }^{77}$ Jelen fejezet a felmerült problémák közül csak a közjogi és jogalkotási kérdések közül érintett néhányat, és a fentiek alapján 2020. decemberben - még az Alaptörvény kilencedik módosítása előtt - a következő kiigazítások tûntek szükségesnek:

1. A jogalkotónak megnyugtató módon összhangba kell hoznia az Alaptörvényt és a Kat.-ot, ezzel elejét venni annak, hogy az Alkotmánybíróság egy esetleges erre irányuló indítvány esetén - akár csak részlegesen - megsemmisítse a Kat. 44. \$-át. Az ütközés feloldása

73 Ezzel ellentétes álláspontra és a jogalkotó részéről felmerülő értelmezési dilemmára lásd: Salgó, 2020, 15. o. A szerző szerint ellentétben állt egymással a nyelvtani és a jogdogmatikai értelmezés, és a jogalkotó az utóbbit követte. Az viszont nem derül ki a szerző gondolatmenetéből, hogy a 2-3. \$-ok miért minősülnének rendkívüli intézkedéseknek.

74 Hangsúlyozom, hogy a fenti megállapításaim nem általában vonják kétségbe a Kevtv.-t és az abban foglalt felhatalmazás létjogosultságát.

75 Tordai, 2020.

76 Salgó, 2020, 9. o.

77 A felülvizsgálat egyik eredménye a Kat. 2020. júniusi - a 21. jegyzetben említett - kiegészítése. 
során az alapkérdés az volt, hogy mit igazítunk mihez, hiszen a probléma mind a Kat., mind pedig az Alaptörvény módosításával kezelhető lenne. Álláspontunk szerint a Kat. tágabb (,inkluzívabb”) veszélyhelyzet-definíciója rugalmasabb reagálást tesz lehetôvé a kormányzat részére, így inkább az Alaptörvény 53. cikk (1) bekezdését lenne célszerủ módosítani.

2. Átgondolásra szorul az Alaptörvény 53. cikk (1)-(3) bekezdése, különösen a három bekezdés egymáshoz való viszonya. Az alkotmányozónak meg kell szüntetnie a Kormány sarkalatos törvényben meghatározott rendkívüli intézkedéseire való duplikált utalást.

3. A jövőben célszerủ lenne egyértelmủen elhatárolni egymástól a veszélyhelyzetet kihirdető, valamint a rendkívüli intézkedéseket bevezetô kormányrendeleteket, felszámolva ezzel a hibrid aktusokat. Mindez tisztább helyzetet teremtene a meghosszabbítás vonatkozásában is.

\section{A veszélyhelyzet korrekciója: az Alaptörvény kilencedik módosítása}

Amint a megelőző fejezetben bemutattuk, a jelen kötet kézirata lezárásának napján, 2020. december 15-én elfogadott kilencedik Alaptörvény-módosítás (a továbbiakban: Módosítás) gyökeresen átalakította az Alaptörvény különleges jogrendre vonatkozó szabályait. ${ }^{78}$ Tekintve, hogy a Módosítást az előző fejezetben részletesen elemeztük, e helyütt csak röviden reflektálunk a fentebb felvázolt javaslatok alkotmányozó általi „megfogadására”.

Elsőként azt kell leszögezni, hogy a veszélyhelyzet kihirdetésére okot adó körülmények a Módosítás nyomán immár nem kerülnek leszúkítésre az elemi csapásra és az ipari szerencsétlenségre, ugyanis ez a két eset csak példálózó módon jelenik meg: „A Kormány az élet- és vagyonbiztonságot veszélyeztető súlyos esemény - különösen elemi csapás vagy ipari szerencsétlenség - esetén, valamint ezek következményeinek az elhárítása érdekében veszélyhelyzetet hirdethet ki. ${ }^{79}$ Ezzel a Módosítás - mutat rá az indokolás - a veszélyhelyzet kihirdetését lehetővé teszi a jelenleg előre nem jelezhetô esetekben is. Ezzel a megoldással álláspontunk szerint elhárultak az Alaptörvény és a Kat. ütközésére hivatkozó aggályok.

Szintén megoldódik a veszélyhelyzet meghosszabbításával kapcsolatos problémák egy része, ugyanis a Módosítás értelmében magának a veszélyhelyzetnek a meghosszabbításához is szükség lesz az Országgyúlés felhatalmazására ${ }^{80}$ (a veszélyhelyzet maximális - meghosszabbítás nélküli - időtartama egyúttal 30 napra emelkedik). ${ }^{81}$ Fentebb utaltunk rá, hogy a jövőben célszerủ lenne egyértelmúen elhatárolni egymástól a veszélyhelyzetet kihirdető, valamint a rendkívüli intézkedéseket bevezető kormányrendeleteket, felszámolva

78 Magyarország Alaptörvényének kilencedik módosítása 11. cikk.

79 Új számozás szerinti 51. cikk (1) bekezdés.

80 Új számozás szerinti 51. cikk (3) bekezdés.

81 Új számozás szerinti 51. cikk (2) bekezdés. 
ezzel a hibrid aktusokat. A Módosítás tükrében ezen kifogás relevanciája csökkent, hiszen a jövőben már nem kizárólag a Kormánytól fog függeni, hogy meddig tart a veszélyhelyzet. Mindazonáltal fenntartjuk az álláspontunkat, hogy áttekinthetôbb és logikusabb lenne, ha a későbbiekben elkülönülnének egymástól a veszélyhelyzetet kihirdetô, illetve a további (rendkívüli) intézkedéseket tartalmazó kormányrendeletek.

Ami a Kormány rendkívüli intézkedéseire való duplikált utalást illeti, a fentebb kifejtett következetlenségek is megszúnnek, ugyanis a Módosításnak az Országgyưlés által elfogadott változata - szemben a javaslat eredeti szövegváltozatával ${ }^{82}$ - a veszélyhelyzetről szóló rendelkezések között - álláspontunk szerint helyesen - már nem tartalmazza, hogy a Kormány „sarkalatos törvényben meghatározott rendkívüli intézkedéseket vezethet be”. ${ }^{83}$ Ez felesleges is lenne, hiszen a Módosítás nyomán az Alaptörvény immár általános hatállyal, valamennyi különleges jogrendre vonatkozóan rögzíti, hogy „[a] Kormány különleges jogrendben rendeletet alkothat, amellyel - sarkalatos törvényben meghatározottak szerint egyes törvények alkalmazását felfüggesztheti, törvényi rendelkezésektől eltérhet, valamint egyéb rendkívüli intézkedéseket hozhat". ${ }^{84}$

Összességében tehát úgy véljük, hogy a veszélyhelyzetre vonatkozó alaptörvényi szabályozás korrekciói több szempontból is előrelépést jelentenek, azonban az is hangsúlyozandó, hogy a különleges jogrendi módosítások csak 2023. július 1-jén lépnek hatályba, így a fejezetben jelzett problémák a gyakorlatban továbbra is fennállnak.

\section{Irodalomjegyzék}

BALÁZs, I., HOFFMAN, I. (2020) 'Közigazgatás és koronavírus - a közigazgatási jog rezilienciája vagy annak bukása?', Közjogi Szemle, 13(3), 1-10. o.

DósA, Á., HANTI, P., KovÁCSY, Zs. (2016) Kommentár az egészségügyről szóló 1997. évi CLIV. törvényhez. 1. kiadás. Budapest: Wolters Kluwer

HojnYÁk, D., UngVáRI, Á. (2020) 'Az Európai Unió egyes tagállamainak koronavírusjárványra adott válasza, különös tekintettel a vizsgált államok által bevezetett különleges jogrendi szabályozásra', Miskolci Jogi Szemle, 15(1), 122-138. o.

82 Lásd a T/13647. számú törvényjavaslatot Magyarország Alaptörvényének kilencedik módosításáról. Elérhető: www.parlament.hu/irom41/13647/13647.pdf (Letöltve: 2020. november 10.). A törvényjavaslat 11. cikke értelmében az Alaptörvény 51. cikk (1) bekezdés helyébe a következő rendelkezés lépett volna: „A Kormány az életés vagyonbiztonságot veszélyeztető súlyos esemény - különösen elemi csapás vagy ipari szerencsétlenség esetén, valamint ezek következményeinek az elhárítása érdekében veszélyhelyzetet hirdethet ki, és sarkalatos törvényben meghatározott rendkivüli intézkedéseket vezethet be." (A kurzivált szövegrész a későbbiekben törlésre került.).

83 Új számozás szerinti 51 . cikk (1) bekezdés.

84 Új számozás szerinti 53. cikk (1) bekezdés. 
LatTmann, T. (2020) Vajon „elemi csapás” egy járvány, van-e alaptörvényi alapja a veszélyhelyzet kihirdetésének? [Online]. Elérhető: https:/lattmanntamas.hu/2020/03/11/vajon-elemicsapas-egy-jarvany-van-e-alaptorvenyi-alapja-a-veszelyhelyzet-kihirdetesenek/ (Letöltve: 2020. november 10.)

MÉszÁros, G. (2019) 'Indokolt-e a különleges jogrend koronavírus idején? Avagy a 40/2020. (III. 11.) Korm. rendelettel összefüggő alkotmányjogi kérdésekről', Fundamentum, 2019/3-4, 63-72. o.

ORBÁN, B. (2020) A járvány vége sajnos egyelóre nem látszik [Online]. Elérhető: https://index. $\mathrm{hu} /$ velemeny/2020/03/22/orban_balazs_miniszterelnokseg_velemeny_veszelyhelyzet_ meghosszabbitasa_felhatalmazas_orszaggyules/ (Letöltve: 2020. október 5.)

SALGó, L. P. (2020) 'A hazai veszélyhelyzeti jogalkotás a kodifikátor szemével', Fontes Iuris, $6(2), 8-18.0$.

SCHIFFER, A. (2020) Különleges jogbizonytalanság [Online]. Elérhető: https:/hvg.hu/itthon/ 20200313_schiffer_kulonleges_jogbizonytalansag_veszelyhelyzet_alkotmanyellenes (Letöltve: 2020. december 2.)

SZENTE, Z. (2020) 'A 2020. március 11-én kihirdetett veszélyhelyzet alkotmányossági problémái', Állam-és Jogtudomány, 61(3), 115-139. o.

TilL, Sz. (2019) 'Különleges jogrend' in Jakab, A., Fekete, B. (szerk.) Internetes Jogtudományi Enciklopédia [Online]. Elérhető: http://ijoten.hu/szocikk/kulonleges-jogrend (Letöltve: 2020. november 16.)

TORDAI, Cs. (2020) A közjog határai a járványveszély idején [Online]. Elérhető: https:// igyirnankmi.atlatszo.hu/2020/03/16/a-kozjog-hatarai-a-jarvanyveszely-idejen/ (Letöltve: 2020. október 5.) 